\title{
İMAM HATIP LISELERINDE DINSEL GELENEKLERIN ÖĞRETIMI: TESPITLER VE TEKLIFLER*
}

\author{
MAHMUT AYDIN* \\ ASIM DURAN**
}

\section{Teaching of Religions in İmam-Hatip Schools: \\ Findings and Suggestions}

Abstract: Some researches which have been done on the teaching of religious traditions in high schools have demonstrated that students are very eager and keen on learning other religions. However these studies put forward two other conclusions: The first one is that students of Imam-Hatip and other schools have not got enough information of non-Islamic religions. And their information of other religions have been obtained not from schools but other sources.

In this article, taking off from the conclusions of the statistical studies which were carried out concerning teaching other religions, first of all it is dealt

\footnotetext{
Bu makale, 23-24 Kasım 2013 tarihinde İstanbul'da düzenlenen "100. Yllında İmam Hatip Okullan Uluslararası Sempozyumu"nda tarafımızca sunulmuş bildirinin gözden geçirilmiş şeklidir

. Prof. Dr., Ondokuz Mayıs Üniversitesi, İlahiyat Fakültesi, Dinler Tarihi ABD. [mahmuta@omu.edu.tr]

.. Arş. Gör., Ondokuz Mayıs Üniversitesi, Dinler Tarihi ABD. [asim.duran@omu.edu.tr] 
with the problems concerning the course called "Comparative History of Religions" which argued that it was prepared in the light of pluralistic worldview. Secondly it is set forth some suggestions concerning those problems. By doing this it is also tried to answer the following questions: Why students of Imam Hatip Schools do not have enough information about other religions although most of them are eager to have information about other religions? What are the main problems concerning the course "Comparative History of Religions" which is given in Imam-Hatip Schools? What kind of solutions can be suggested concerning Comparative History of Religion course both theoretically anf practically?

Key Words: Religious Pluralism, Imam-Hatip School, Comparative History of Religions, Teaching Other Religions.

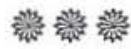

Öz: Orta öğretim kurumlarında dinsel geleneklerin öğretilmesiyle ilgili son yıl2 larda yapılan bazı çalışmalar, öğrencilerin diğer dinleri öğrenme konusunda 20 önemli ölçüde istekli olduklarını göstermektedir. Ancak aynı çalışmalardan OMÜiFD elde edilen diğer bir sonuç, hem İmam Hatip Lisesi hem de diğer orta öğretim öğrencilerinin söz konusu dinler hakkında yeterli bilgiye sahip olmadıkları ve sahip oldukları bilgileri de çoğunlukla örgün eğitim kurumlarından ziyade dış kaynaklardan elde ettikleridir.

Bu makalede söz konusu anket çalışmalarının sonuçlarından hareketle, İmam Hatip Liselerinde okutulan ve "çoğulcu" perspektifle yazıldığı söylenen "Karșılaştırmahı Dinler Tarihi" dersiyle ilgili sorunlara değinilecek ardından bunlarla ilgili çözüm önerileri sunulmaya çalışılacaktır. Bu bağlamda, İmam Hatip Lisesi öğrencilerinin büyük bir çoğunluğu İslam dışındaki dinlerin öğretilmesine olumlu yaklașmalarına rağmen, neden bu dinler konusunda yeterli bilgiye sahip değildirler ve bu hususta neler yapılabilir? Adı geçen okullarda okutulan "Karşılaştırmalı Dinler Tarihi" dersiyle ilgili problemler nelerdir? Söz konusu problemlerin çözümü için hem teorik hem de pratik düzeyde neler önerilebilir? Makalede temelde bu soruların cevabı aranacaktır.

Anahtar Kelimeler: Dinsel Çoğulculuk, İmam Hatip Lisesi, Karşılaştırmalı Dinler Tarihi, Diğer Dinlerin Öğretimi 


\section{Ġiriş}

Ülkemizde Milli Eğitim Müfredatında son ylllarda yaşanan değişiklikler neticesinde gerek ilköğretim ve ortaöğretimdeki “Din Kültürü ve Ahlak Bilgisi" dersinde, gerekse İmam Hatip liselerinde okutulan "Karşılaştırmah Dinler Tarihi" dersinde, dünya dinlerine geçmiş yllara oranla daha fazla ağırlık verdiği görülmektedir. Bunun yanında İslam dışı dinsel geleneklere yönelik yaklaşımlarda da bakış açılarının değiştiğine de şahit olmaktayız. Öyle ki bu süreçte savunmacı ve karşılaştırmaya dayanan bir anlatımdan -ciddi eksiklikler olmakla birlikte- çoğulcu ve yapılandırmacı bir yaklaşıma doğru kayan bir geçişin olduğu dikkatten kaçmamaktadır. ${ }^{1}$ Bu bağlamda, İmam Hatip Liselerinde okutulan Karşllaştırmalt Dinler Tarihi Öğretim Programı́nın genel amaçlar bölümüne (özellikle 8. madde) bakıldığında "çoğulculuk" fikrinin, dinsel geleneklerin öğretilmesinde bir perspektif olarak kullanıldığı görülmektedir. ${ }^{2}$

Bu makalenin amacı, Türkiye'de İmam Hatip liselerinde ve diğer orta öğretim kurumlarında İslam dışı dinlerin ve inançların öğretiminde yaşanan değişiklikleri ele almak, tarihsel ve metodolojik sürece dikkat çekmek değildir. Bununla ilgili hem bilimsel makaleler hem de değişik sempozyumlar da sunulmuş bildiriler ve çeşitli dergilerde yayınlanmış makaleler hâlihazırda mevcuttur. ${ }^{3}$ Ayrıca bu çalışmada, genel olarak dinler tarihinin öneminden de bahsedilmeyecektir. Bunun yerine daha özel

1 Recep Kaymakcan, "Türkiye'de Din Eğitiminde Çoğulculuk ve Yapılandırmacılık: Yeni Ortaöğretim DKAB Programı Bağlamunda Bir Değerlendirme", Kuram ve Uygulamada Ĕ̈itim Bilimleri, 7 (1), Ocak 2007, ss. 198-201.

2 MEB, "Karşılaştırmalı Dinler Tarihi Öğretim Programı", Imam Hatip Lisesi ve Anadolu İmam Hatip Lisesi Öğretim Programı İçinde, ss. 209-239, http://dogm.meb.gov.tr/ www/ogretim-programlari/icerik/14, (Erişim: 20 Ağustos 2013).

3 Bkz. Recep Kaymakcan, "İmam Hatip Liselerinde Dinler Tarihi Öğretimi", Imam Hatip Liselerinde Ë̆itim ve Öğretim İçinde, İstanbul: DEM Yayınları, 2005, ss. 333-351; Cemal Tosun, "Cumhuriyet Dönemi Din Dersi Öğretim Programlarında Diğer Dinler", Dinler Tarihi Araştırmaları VII, Türkiye'de Dinler Tarihi İçinde, İstanbul: Türkiye Dinler Tarihi Derneği Yayıları, 2010, ss. 655-672; Zübeyir Bulut, "Dinsel Çoğulculuk ve Ortaöğretim Din Kültürü ve Ahlak Bilgisi Dersinde Diğer Dinlerin Öğretimi", Kelam Araştırmaları, 8 (2), 2010, ss. 65-90. 
ve meselenin arka planına vurgu yapan bir arayışla, ağırlıklı olarak din hizmeti alanında görev alan İmam Hatip Lisesi öğrencilerine diğer dinleri tanitmann önemine; söz konusu okullarda okutulan "Karşlaştırmalı Dinler Tarihi" dersiyle ilgili temel ve pratik sorunlara ve bunların çözümüne yönelik tekliflere değinilecektir. Buna göre, İmam Hatip lisesi öğrencileri için dinsel geleneklerin öğretilmesinin önemi nereden kaynaklanmaktadır? Adı geçen okullarda okutulan "Karşılaşturmalı Dinler Tari$\mathrm{hi}^{\prime \prime}$ dersiyle ilgili problemler varsa bunlar nelerdir ve söz konusu problemlerin çözümü için hem teorik hem de pratik düzeyde neler önerilebilir? şeklindeki sorular, bu yazının temel soruların oluşturmaktadır.

\section{Problemin Kaynağı}

Yukarıda ifade ettiğimiz soruların cevabın aramaya bizleri iten temel sebeplerden ilki, ilahiyat fakültelerinde ve İmam Hatip liselerinde oku-

22 yan azımsanamayacak derecedeki öğrenci kitlesinin İslam dışı dinsel $\overline{\text { nüiFD }}$ gelenekler konusunda yeterli bilgiye sahip olmadıkların görmemiz oldu. Aslında bu, yllardır birçok akademisyen ve İmam Hatip Lisesi meslek dersi öğretmenleri tarafindan dile getirilen ortak bir kanaat olmuştur. Gerek yıllardır ilahiyat fakültelerinde ders veren birisi olarak yaşadığımız tecrübeler, gerekse diğer meslektaşlarımızla yaptığımız müzakereler ve toplantılardan çıkan sonuçlar, bizde böyle bir kanaatin oluşmasına sebep oldu. İkincisi, çeşitli unvanlarla din hizmetini yürüten görevlilerin, değişik ortamlarda diğer dinsel gelenekleri değerlendirirken ve eleştirirken çoğunlukla kulaktan dolma ve yanlış bilgilerden hareket ettikleri gerçeğidir. Özellikle Asya dinleri söz konusu olduğunda yapılan hataların azımsanamayacak derecede olduğu herkesin malumudur. Bu sorun, hem İmam Hatip liselerinde hem de ilahiyat fakültelerinde dinsel geleneklerin öğretilmesinde kaynak probleminin hâlâ çözülemediğinin bir göstergesi olarak anlaşılabilir. Üçüncüsü, dinler tarihi öğretiminin belli bir dinsel geleneğin ön kabullerinden hareketle yapılması ve bunun diğer dinsel geleneklerin öğretilmesinde çoğunlukla önyargılı ve taraflı yaklaşımlanı tetiklemesi. Burada "Karşılaştırmalı Dinler Tarihi" dersinde teolojik ön 
kạbullerin ve taraflı bakış açılarının diğer dinsel geleneklerin anlam dünyalarını ve kültürel farklılıkların nedenlerini keşfetmede ciddi engel teşkil ettiğini ifade etmek gerekir. Yeryüzündeki tüm dinsel geleneklerin tek bir dinin teolojik zemininden hareketle belli bir çerçeveye oturtulmaya çalışlması, farkh teolojik kavramlarla ilgili neticede "anlam kayma"larına sebep olacağı muhakkaktır. Batıda da benzer tartışmaların yapıldığı dikkate alındığında bu sorunun, sadece bu ülkeye ait bir mesele olmadığı, genel olarak teoloji ve dini ilimlerin temel problemlerinden birisi olduğu görülecektir. ${ }^{4}$ Son olarak, diğer dinsel gelenekleri öğrenmenin dini samimiyeti ortadan kaldıracağı ve kişisel inanca zarar vereceği şeklindeki kanaatlerin varlığın da burada hatırlanabilir. $\mathrm{Bu}$, sorunun görünenin ötesinde daha derin bir zeminden kaynaklandığın göstermesi açısından önemlidir. Zira günümüzde din hizmetleri alanında görev yapan belli kesimlerin İslam dışındaki dinleri öğrenmeye karşı hâlâ ihtiyath yaklaştkkları bilinmektedir.

Ancak son yıllarda yapılan araştırmalar ve anket çalışmaları, bu huOMÜiFD susta toplumda ciddi bir değişimin yaşandığının ipuçların bize vermektedir. Özellikle -yazımızla bağlantılı olarak- ortaöğretim okullarında ve İmam Hatip liselerinde okuyan öğrencilerin diğer dinleri öğrenme konusunda istekli oldukların ortaya koyan araştırmaları burada zikretmekte fayda var. Örneğin Hüseyin Yulmaz'ın bu konudaki çalışmasına bakıldığında ortaöğretim kurumlarındaki öğrencilerin büyük bir çoğunluğu (\% 73.66) "İslam dişındaki dinler öğretilmeli mi?" sorusuna olumlu cevap verdikleri görülmektedir. İmam Hatip Lisesi öğrencilerinin ayn soruya verdikleri cevap ise \% 92.85'i bulmaktadır. ${ }^{5}$ Ayn anket çalışmasında

4 Bkz. Paul Knitter, "Beyond A Mono-Religious Theological Education", In Shifting Boundaries: Contextual Approaches to the Structure of Theological Education, (Eds.) Barbara G. Wheeler \& Edward Farley, Louisville: John Knox Press, 1991, ss. 151-180; F. S. Fiorenza, "Theological and Religious Studies: The Contest of the Faculties", In Shifting Boundaries: Contextual Approaches to the Structure of Theological Education, ss. 119-149.

5 Hüseyin Yllmaz, "AB'ye Giriş Sürécinde Ortaöğretimde Diğer Dinlerin Öğretimi İe İlgili Öğrencilerin Düşünceleri", Cumhuriyet Üniversitesi İlahiyat Fakïltesi Dergisi, 8 (2), 2004, s. 116. 
İmam Hatip Lisesi öğrencileri "İslam dışındaki dinler hakkındaki bilgilerinizi yeterli buluyor musunuz?", sorusuna ise \% 41.66 oranunda olumlu cevap vermişlerdir. Diğer ortaöğretim kurumlarındaki öğrencilerin ayn soruya verdikleri olumlu cevap \% $15^{\prime}$ lere kadar düşmektedir. ${ }^{6}$ Gerçi söz konusu anket çalışması, yerel ölçekte sadece Sivas ilini kapsamasına rağmen yine de genel durumu görmek için bize bir takım ipuçları verebilir.

Benzer bir anket çalı̧̧masında da İmam Hatip Lisesi dışındaki ortaöğretim öğrencilerinin diğer dinlerin öğretilmesine yönelik tutumların olumlu olduğu görülmektedir. Hatta bu hususta diğer dinlerin öğretilmesinin dünya barışına katkı sağlayacağına dair ciddi bir kanaat de (\% 84.9) söz konusudur.7 Ancak ankete katilan öğrencilerin büyük bir çoğunluğu, diğer dinler hakkındaki bilgilerini ya kısmen ya da tamamen yetersiz buldukların belirtmişlerdir. Yeterli görenlerin oran neredeyse \% 10'lara kadar düşmektedir. Yine ayn anket çalışmasında farklı din mensuplarıOMÜiFD inn diyalog faaliyetleriyle birbirlerini anlamaya çalışmaları gerektiği konusunda öğrencilerin ciddi bir kesiminin (\% 44.6) olumlu yaklaşımlar göze çarpmaktadır. ${ }^{8}$

Konuyla ilgili diğer bir çalışmada ise ortaöğretim öğrencilerinin di ğer dinlerle ilgili kanaatlerinin ve bilgilerinin kaynağı sorgulanmış v ankete katılan öğrenciler, \% 38.5 oranunda ders kitaplarından; \% 53.1 ora nunda Din Kültürü ve Ahlak Bilgisi öğretmenlerinden; \% 37.5 oranınd: televizyonlardaki yabanc dizi ve filmlerden; \% 28.1 oranunda ise cami lerdeki vaazlardan ve hutbelerden yoğun bir şekilde faydalandıkların

6 Yllmaz, "AB'ye Giriş Sürecinde Ortaöğretimde Diğer Dinlerin Öğretimi Ille İlgili Öğren cilerin Düşünceleri", s. 119.

ᄀ Zeynep Baykara, “Okullarda Din Kültürü ve Ahlak Bilgisi Derslerinde Diğer Dinlerin Öğretimi", Yaymlanmamış Yüksek Lisans Tezi, (Sakarya Üniversitesi Sosyal Bilimler Enstitüsü, 2009), s. 51.

8 Baykara, "Okullarda Din Kültürü ve Ahlak Bilgisi Derslerinde Diğer Dinlerin Öğretimi", ss. 43-49. 
ifade etmişlerdir. Bu oranların dışında kalan çoğunluk kitle ise ya az faydalandıklanın ya da hiç faydalanmadıklanını söylemişlerdir. ${ }^{9}$

Söz konusu anket çalışmalarından bu çalışmanun amacı açısından şöyle bir sonuç ortaya çıkmaktadır: Hem İmam Hatip Lisesi öğrencileri hem de diğer ortaöğretim öğrencileri, genel olarak eğitim kurumlarında İslam dışındaki dinlerin öğretilmesinde bir sakınca görmemektedirler. Bilakis olumlu baktıkları bile söylenebilir. Ancak anket çalışmalarından elde ettiğimiz diğer bir sonuç ise, bahsi geçen öğrencilerin diğer dinler konusunda yeterli bilgiye sahip olmadıkları ve sahip oldukları bilgileri de eğitim kurumlarından değil de daha çok dış kaynaklardan elde ettikleridir. Söz konusu çalışmalara, İmam Hatip Lisesi öğrencilerinin dinsel geleneklere yönelik yeterlikleri ile ilahiyat fakültesi öğrencilerinin yeterlikleri arasında önemli bir fark olduğunu ortaya koyan çalışmaları da eklemekte fayda var. ${ }^{10}$

O halde, burada cevaplanması gereken soru şudur: İmam Hatip Li- OMüifD sesi öğrencilerinin büyük bir çoğunluğunun İslam dişındaki dinlerin öğretilmesine olumlu yaklaşmalarına rağmen, neden bu dinler konusunda yeterli bilgiye sahip değildirler ve bu hususta neler yapılabilir? Bu soru, problemin kaynağınun çoğunlukla öğrenci dışındaki unsurlarda aranması gerektiğine işaret etmektedir. Bunlar, bilgilerin muhtevası, kaynağı, yöntemi, materyallerin niceliği-niteliği ve güvenirliği sorunudur. Burada, bilginin muhtevası ve kaynağı sorununa özellikle eğilerek konuyu ders program, kaynak (ders kitapları) ve öğretmen yeterlikleri açısından tartşacağız. Ancak bundan önce dinler tarihi dersinin çağdaş toplumlardaki pratik işlevini saptamakta ve meselenin genel yönüne bak-

9 Altaş, Nurullah, "Liselerde Öğrencilerin Diğer Dinlere Karşı Tutumlanı (Ortaöğretim Din Kültürü ve Ahlak Bilgisi Öğretim Programlarında İslam Dini Dışındaki Dinlerin Öğretimi ve Uygulamaya Etkileri)", Dinler Tarihi Araştırmalan VII, Țürkiye'de Dinler Tarihi İçinde, İstanbul: Türkiye Dinler Tarihi Derneği Yayınları, 2010, ss. 681-683.

10 Mevlüt Kaya \& İbrahim Turan, "İlahiyat Fakültesi ve İmam-Hatip Lisesi Son Sinf Öğrencilerinin Din Görevliliğine İlişkin Mesleki Yeterlilik Alglan (Samsun İli Örneği)", OMÜIFD, 34, 2013, ss. 5-36. 
makta fayda var. Yapacağımız kısa saptamalar, ders kitaplan ve öğretmen yeterliklerini sorgulamada bize önemli imkânlar tanyyacaktır.

\section{Çoğulcu Perspektif: Kültürler Arası İletişim Aracı Olarak Dinler Tarihi}

Günümüzde sadece dinler tarihi dersinin değil genel anlamda teoloji ve dini ilimler eğitiminin temel sorunlarından biri, söz konusu ilimlerin hâlihazırdaki dinsel inanışların canlılığın ve sürekliliğini yansıtamaması olarak gösterilmektedir. Belli kavramsal analizlere sıkıştırılmış bir teoloji ve din ilimleri, pratikle ilişkisini kuramadığı müddetçe aktüel yaşam biçimlerinin olanakların göremeyecektir. Zira sosyal bilimler kapsamunda değerlendirilen fikirler, günlük yaşamla iç içe bir yapı arz ettiği için toplumsal dünyanun dinamiklerini kavramaya yönelik bir çabayı ifade eder.

Bu noktada Paul Knitter'in Huristiyan teolojisine yönelik eleştirisini !6 aktarmakta fayda var. Ona göre Hıristiyan teolojisinin bugün sıkıntılı bir

FD durumda olması, kendini yüceltilmiş ve izole edilmiş bir evin -dışarıya çımanın korkusu- içinde kilitlemesidir. Bu soruna yönelik önerisi ise kim olduğumuzu ve bir evimiz olduğunu unutmadan, kültürel-politik bağlamın (geçmiş ve şimdi) farkında olan bir çabayla kilitlerden kurtulmaktır. Zira bugün postmodern kültürel ilişkilerimiz çoğulculuğu zorunlu kulmakta, hatta övmektedir. ${ }^{11}$

Knitter, her ne kadar tarafımızdan eleştirilebilir gözüken uç örneklerle sorunu çözmeye çalışsa da yazımız açısından onun soruna yönelik saptaması ve "kültürler arası ilişkiye" yaptığı vurgu dikkate değerdir. Zira hâlihazırda hem İmam Hatip liselerinde hem de ilahiyat fakültelerinde dinsel geleneklerin öğretiminde benzer sorunlarla karşı karşıya olduğumuzu görmek hiç de zor olmayacaktır. Bugün ülkemizdeki dini ilimler -özelde dinler tarihi-, kültürel etkileşimin şartlarından ve imkânlarından izole edilmiş gibi gözükmektedir. Diğer dinsel geleneklerin mensuplanı, yaşadığımız toplumuz "içinde" bir yerlerde karşlaşabilece-

1 Knitter, "Beyond A Mono-Religious Theological Education", ss. 153-154. 
ğimiz kimseler olarak değil, bizim dışımızda ve bizimle herhangi bir bağı olmayan "dışarıda" birileri olarak anlatılmaktadır. Dahası dinsel geleneklerin öğretiminde kısmen alaycı bakışı da içeren eğilimlerin yaygın olduğu da bir gerçektir. Bu tarz eğilimler, neticede diğer din mensuplarının anlam dünyalarına ve yaşam biçimlerine "kapalı" olmayı kışkırtmakta ve söz konusu kişilerle iletişimimizde ciddi sorunlara yol açmaktadır. Belki de mevcut dinler tarihi öğretiminin pratik açıdan bizi karşıı karşıya bıraktığı en ciddi sorun, gayr-1 Müslimlerle kültürel açıdan "yüzleşmẹe" sorunudur. ${ }^{12}$ Herhangi bir şekilde gayr-1 Müslimlerle karşılaşan kimse, dinler tarihi dersinde verilen bilgilerin sağlıkh bir "yüzleşmeye" imkân tanımadığının rahatsız edici tecrübesini yaşayacaktır. Böyle bir karşlaşmada hangi tarafın daha sağlıklı bir iletişim kuracağı hiç de şaşırtıcı olmayacaktrr. Bu bakımdan yazımızın başında aktardığımız üzere öğrencilerin, diğer dinsel gelenekleri öğrenme konusunda istekli olduklarına dair anket sonuçları dikkate alındığında, dinler tarihi öğretiminin öğrencilerin kültürel iletişim isteklerini karşılama bakımından yetersiz olduğu rahatlıkla görülebilir.

O halde hem İmam Hatip liselerinde hem de ilahiyat fakültelerinde çoğulcu toplumların bir gereği olarak "kültürler arası iletişim" ve diğer din mensuplarıyla "yüzleşme" mize yardım edecek bir dinler tarihi dersi pratik düzeyde neleri öncelemelidir? Bunun için neler önerilebilir?

Böyle bir sorunun cevabı, öncelikle dinler tarihi dersinde nelerin olmaması gerektiğinden hareketle verilebilir. Buna göre, artık günümüz ̧̧artlarında dinler tarihi dersinde hedef sadece dinsel gelenekleri öğrenmek olmamalıdır. Söz konusu dinlerin var olma, dünyayı anlamlandırma jiçimleri ve bu anlam biçimlerinin pratik yaşamla ilişkisinin ortaya konması da bu derste özellikle dikkate alınmalıdır. Bu, çoğulcu bakışın ve кültürler arası iletişimin yaygın olduğu toplumlarda saygı merkezli bir

i Dini ağırlıklı eğitim alan öğrencilerin modern dünya ile yüzleşme sorununa dair bkz. Burhanettin Tatar, "Günümüzde İlahiyat Fakültelerinde Tefsir, Hadis, Ahlak Felsefesi ve Müzik Derslerinin Anlamu Üzerine Notlar", Süleyman Demirel Üniversitesi İlahiyat Fakiiltesi Dergisi, 1 (3), 2013, ss. 85-90. 
iletişim için kaçınulmazdır. Knitter'in ifadesiyle söylersek, dinler tarihi dersinde, dinsel geleneklerin anlam ve gerçeğe yönelik sorularına cevap verilmedikçe onların iddialarına saygı göstermek zordur. ${ }^{13}$

Şayet böyle bir iddianın geçerliliği varsa, sadece açıklamaya dayanan bir dinler tarihi öğretiminin çoğulcu ve saygı merkezli olmaktan uzak olacağı da kabul edilmiş olunacaktır. Toplumsal yaşam biçimlerinin dikkate alınmadığı ve teolojik ön kabullerden hareketle yapılan bir dinler tarihi öğretiminin, "ötekini anlama" ve "bir arada yaşama"ya katkı sağlayamayacağı açıktr. Zira Knitter'e göre dinlerin öğretimi, din ile hâlihazırdaki kültürler arasında diyalojik bir ilişsi kurma biçimi olarak düşünülmelidir. ${ }^{14} \mathrm{Bu}$ anlamda dinler tarihi dersi, bir dinsel geleneğin toplumsal dinamiklerden kopuk bir şekilde anlatılması değildir. Aksine böyle bir dersle bir kültür hakkında da bilgiler elde edilerek kültürler arası etkileşimlerin olanakları keşfedilmiş olur. Ayrıca dinler tarihi dersinin dinsel $\overline{\text { JMÜiFD }}$ geleneklerden hareketle, diğer kültürlerle diyalojik ilişki kurmada önemli bir yere sahip olduğu burada ifade edilebilir. Bu anlamda söz konusu ders, teolojik ön kabullerin belli kavramlar çerçevesinde verildiği bir ders değil "kültürler arası bir iletişim biçimi"dir. Dolayısıyla bu dersi alan öğrenci, sadece dinsel inanış biçimlerini teorik olarak öğrenmekle kalmaz, bunun yanında diğer kültürler ve onların anlam dünyaların da keşfetmiş olur. Dinler tarihi dersi, ne ölçüde toplumsal yaşamın dinamiklerini keşfetmeye ve dinle birebir ilişkili olan kültürel kimlikleri anlamaya yönelirse, o kadar diğer kültürlerle yüzleşmeye korkmayan nesiller yetiştirecektir. Zira yaşadığımız dünya zaten söz konusu iletişimi ve etkileşimi zorunlu kılmaktadır. Bu anlamda öğrencileri diğer din mensuplarıyla "yüzleşmeye" ve "iletişime" hazırlamak dinler tarihi dersinin de sorumluluğu altındadır.

Bu açıklamalarımuz doğru kabul edildiğinde ve orta öğretimdeki öğrencilerin diğer dinsel gelenekleri öğrenme konusundaki istekli oldukla-

13 Knitter, "Beyond A Mono-Religious Theological Education", s. 172.

14 Knitter, "Beyond A Mono-Religious Theological Education", s. 172. 
rına dair anket çalışmaları dikkate alındığında hem ders müfredatı ve kitabının hem de öğretmen yeterliklerinin bu bağlamda tartı̧ılması pratik açıdan bize fayda sağlayacaktır.

\section{Dinsel Geleneklerin Öğretiminde Bir Kaynak Olarak Ders Müfredatı ve Kitabı}

İmam Hatip liselerinde "Karşılaştırmalı Dinler Tarihi" dersinin öğretiminde genel olarak iki kaynak ön plana çıkmaktadır: İlki ders kitabı, diğeri ise öğretmendir. Etki bakımından başka faktörlerden de bahsedilebilir. Ancak resmi müfredat açısından ve örgün eğitiṃin prensipleri bakımından bu ikisinin ön plana çıtığın söyleyebiliriz. İmam Hatip liselerinde ve diğer ortaöğretim kurumlarında diğer dinlerin öğretilmesinde ders kitaplarının önemli bir yere sahip olduğu herkesin malumudur. Ancak hâlihazırda İmam Hatip liselerinde okutulan "Karşılaştırmalı Dinler Tarihi" ders kitabı, ${ }^{15}$ diğer dinlerin öğretilmesinde ne derece yeterliğe sahiptir? Söz konusu ders kitabı, programın amaçlarında belirtilen husus29 ları yansıtabilmekte midir? Diğer dịsel geleneklerin öğretiminde çoğulcu bakış açına doğru bir sürecin yaşandığı günümüzde "Karşlaştırmahı Dinler Tarihi" ders kitabı, bu süreçte "kültürler arası iletişim"e ne ölçüde katkı sağlayabilmektedir? Bu konuda neler önerilebilir?

Tüm bu soruların anlaml bir cevabının olabilmesi için İmam Hatip liselerinde diğer dinlerin öğretilmesinin gerekliliğinin ortaya konması gerekir. Artık şu çok iyi bilinmektedir ki sınırların ortadan kalktığı, dinsel ve kültürel çoğulculuğun bir gerçeklik haline geldiği günümüz dünyasında başka inanç mensuplarıyla bir arada yaşama ve onların inançlarına anlayış göstererek diyalojik ilişki kurmanın gerekliliği yaygın bir kanaat halini almıştır. Farklı dinsel geleneklere sahip olan toplulukların birbirleriyle ilişki kurabilmeleri; özellikle günümüz dünyasında bir zorunluluk halini alan medeniyetler arası barışın sağlanması; globalleşen dünyamızda insanlığın yüz yüze kaldığı insan onuru ve hakları konusundaki bir

15 Özbay, E. \& Diğerleri, İmam Hatip Liseleri Karşılaştırmalt Dinler Tarihi Ders Kitabı, Ankara: Milli Eğitim Bakanlı̆̆ Yayınlanı, 2010. 
takım ihlallerin çözümü konusunda dünya dinlerinin önerilerinin, temel ahlak öğretilerinin ve dünya görüşlerinin ön plana çıkarılması gerekmektedir. Bunun ilk aşaması söz konusu dinsel geleneklerin, taraflarınun yaşamlarında yansıdığı şekliyle bilinmesine olanak tanuyacak bir eğitimöğretim faaliyetinin yaygınlaştırılmasıdır. ${ }^{16}$

Din hizmetleri alanında eğitim veren kurumların ilk basamağı olarak kabul edilen İmam Hatip liselerinde bu amaçla genel dinler tarihi dersine ihtiyaç duyulduğuna ve mevcut "Karşılaştırmalı Dinler Tarihi" adlı dersin bu amacı karşılayamadığına yıllar önce bir bildiride işaret edilmişti. ${ }^{17}$ Günümüzde İmam Hatip liselerinde okutulan ayn adlı dersin -bir takım iyileştirmeler olmakla birlikte- koşulların hızlı ilerlemesi karşısında yine yetersiz kaldığın belirtmemiz gerekir.

Öncelikle söz konusu dersin ismiyle ilgili bazı problemlerin ortadan 30 kaldırılması gerekmektedir. Zira isminden de anlaşlacağı üzere dinsel OMÜifD gelenekleri, benzer ve farkh yönleriyle karşılaştırmah olarak öğretmeyi amaçlayan bir içerikle karşı karşıyayız. Buradaki dikkatleri çekmek istediğimiz temel sorun, genel bir dinler tarihi dersi okutulmadan, dinsel geleneklerin karşlaştırmasının bir takım zorluklarla karşılaşılacağı gerçeğidir. Dinsel gelenekler, kendi anlam dünyaları ve mensuplarının yaşamlarında karşlık bulduğu şekliyle fenomenolojik yaklaşımla öncelikle öğrenciye tanitilmadığı takdirde, söz konusu geleneklerin karşılaştırmasında normatif ve dogmatik ön kabullerin hâkimiyeti ortaya çıkacaktır. $\mathrm{Bu}$ da öğretmenin dünya görüşünün, dersin anlatılmasında ve dinsel geleneklerin karşılaştırılmasında belirleyici bir unsur olmasına sebep olacak ve programı, -temel amaçlan ne olursa olsun- öğretmenin bakış açısının sınurlarına mahkûm edecektir. Yükseköğretimde, öğretmenlerin bakış açların yönlendirecek çoğulcu ve fenomenolojik yaklaşımlarla dinsel geleneklerin öğretilmene ağırlık verilse bile bu kontrol edilebilir

16 Mahmut Aydın, "Dinler Tarihi Dersi Amaç, Yöntem, Muhteva ve İşlenişi", İmam Hatip Liselerinde Ĕ̆itim ve Öğretim İçinde, İstanbul: DEM Yayınlan, 2005, s. 355.

17 Aydın, "Dinler Tarihi Dersi Amaç, Yöntem, Muhteva ve İşleniş̧i", ss. 355-356. 
bir durum değildir. Çoğu zaman dinsel geleneklerin karşılaştırılmasında öğretmenin yaklaşım tarzı baskın olmaktadır. Bu bakımdan öncelikle İmam Hatip liselerinde genel dinler tarihi dersinin verilmesi önem arz etmektedir.

"Karşılaşturmalı Dinler Tarihi" dersiyle ilgili diğer bir sorun, karşılaşturma yapılacak öğretilerin ve fenomenlerin dinsel geleneklerde birbirinin muadili olup olmadığı veya söz konusu geleneklerin hangi açlardan käşıllaşturılacağıdır. Zira inanç merkezli yapılacak bir karşılaştırma ile ahlaki prensipler noktasında yapılacak bir karşılaştırma farklı sonuçlara yol açacaktır. Haddizatında bir dinsel gelenekteki herhangi kavramin diğer dinde karşlığı olmayabilir ya da benzer kavramlar farklı dinlerde değişik anlamlara gelebilir. Mesela namaz, oruç, hac gibi ibadetler dinsel geleneklerde temelde aynı niyeti taşıyormuş gibi gözükse de farklı dinsel geleneklerde çok çeşitli amaçlara ve anlamlara sahiptirler. Hepsini tek bir amaç etrafında toplamak, belli bir bakış açısından hareketle anlamaya çalışmak olacaktır ki bu da nihayetinde dinsel geleneklerin kendi anlam dünyaların saf dışı tutmak manasına gelecektir. Örneğin, İslam dinindeki namaz ibadeti ile Asya dinlerinde değişik şekillerde karşımıza çıkan secde etme ritüelini ne derece karşlaştırabiliriz? Ya da bir Hindu'nun anlam dünyasında Ganj; bir Yahudi'nin anlam dünyasında ağlama duvarl; samimi bir Hıristiyan'ın tüm inancın yönlendiren Tanrı'nun Krallığı ve bir Müslüman'ın anlam dünyasında Kâbe, muhataplarına aynı şeyleri mi ifşa eder? Dolayısıyla kavramlar, birbirine yakın olsalar bile her bir kavramin ve ritüelin, o dinin mensupları nezdinde yansıması farklı olacaktır. Zaten insanların farklı dinsel öğretilere bağlanmalarını sebeplerinden birisi de budur.

Bu bakımdan İmam Hatip liselerinde Karşlaştırmalı Dinler Tarihi dersinden önce "Dünya Dinleri" veya "Yaşayan Dünya Dinleri" adı altında dinsel geleneklerin öne çıkardıkları fenomenler arasında herhangi bir karşlaştırma yapmadan fenomenlerin, kendi içinde bir anlam ifade edecek şekilde oldukları gibi ve mensuplarını yaşamlarında karşılık 
buldukları şekliyle ele alınacağı bir dersin mutlaka verilmesi gerekir. ${ }^{18} \mathrm{Bu}$ aşama geçildikten sonra dinsel geleneklerin karşılaştırmalı olarak öğrenciye öğretilmesi daha uygun olacaktır. Zaten fenomenlerin her dinsel geleneğin kendi mekân ve zaman tasavvuru çerçevesinde anlamlandirildığın gören öğrenci, söz konusu gelenekleri karşlaştırırken teolojik ve dogmatik ön yargilara kendisini çoğunlukla kaptırmayacaktır. Bu noktada, yıllar önce sunulmuş bir bildiride Recep Kaymakcan'ın, "objektif yaklaşımla orta dereceli okul düzeyinde dinleri öğretmek uygun mudur?" şeklindeki sorusunu hatırlamakta fayda var. ${ }^{19}$ Bizim savunmaya çalıştğımız önerinin kritik noktası şudur: Dinsel gelenekleri inanç, ibadet ve ahlak açısından karşılaştıran bir dersten önce söz konusu gelenekleri kendi anlam dünyalanı içerisinde ve taraftarlarını yaşamlarında yansıdığı şekliyle anlatacak genel bir dinler tarihi dersinin öğretilmesidir: Kaymakcan'ın söz konusu bildiride de ifade ettiği gibi bir dinsel geleneği, mensupları için ne ifade ettiğini yansıtacak şekilde sunan bir ders, öğren$\overline{\text { OMÜiFD }}$ cilerin derse ilgilerini daha da artıracağı gibi yaşadıkları dünyayı iyi tanumalarına da yardımcı olacaktır..$^{20}$ Yoksa biz burada, dinlerin karşılaştrmalı olarak İmam Hatip öğrencilerine verilmesine itiraz etmiyoruz.

Ders kitabıyla ilgili olarak değinilmesi gerekli olan diğer bir nokta da programun temel amaçlar bölümünde ifade edilen çoğulculuğun ve bir arada yaşama kültürünün öğrencilerde oluşturulması meselesidir. Hâlihazırdaki programa bakıldığında bu amaç "Toplumsal barış için dinî çoğulculuğun önemini kavrayarak farklı dinlere inananların birbirlerini tanımalarının önemini söyler" cümlesiyle özetlenmiştir. ${ }^{21}$ Burada dikkat çeken nokta çoğulculuğun sadece toplumsal barış ve toplụmların birbirini tanımaları açısından ele alınmış olmasıdır. Bu amaç nedeniyle olsa gerek, "Karşılaştırmalı Dinler Tarihi" ders kitabında da çoğulculuk konu-

18 Aydın, "Dinler Tarihi Dersi Amaç, Yöntem, Muhteva ve İşlenişi", ss. 355-358.

19 Kaymakcan, "İmam Hatip Liselerinde Dinler Tarihi Öğretimi", s. 350.

20 Kaymakcan, "İmam Hatip Liselerinde Dinler Tarihi Öğretimi", s. 351.

21 MEB, "Karşılaştırmalı Dinler Tarihi Öğretim Programı", s. 210. 
su, sadece bu açılardan ele alınarak bir değerlendirmeye tabi tutulmuş.22 Yukarıda ifade ettiğimiz üzere meselenin bu pratik yönü önemlidir. Ancak dini çoğulculuk (religious pluralism) ifadesiyle biz, tek bir mutlak doğru üzerine vurgu yapmak veya bu mutlak doğru dini, diğer dinsel geleneklerin mensupların da içine alacak şekilde kapsayıcı hale getirmek yerine, her dinsel geleneğin kendi başına diğerlerinden bağımsız olarak taraftarların kurtuluşa götürebileceği varsayımından hareket eden felsefi bir düşünceyi kastediyoruz. Bu bakımdan dinsel çoğulculuk, dışlayıcılık (exclusivism) ve kapsayıcılık (inclusivism) şeklindeki düşüncelerin ilerisine geçmeyi ifade eder. ${ }^{23}$ Söz konusu kavramların her biri hakikati anlamaya ve kutsah tecrübe etmeye yönelik değişik yaklaşımların ve çabaların yansımalarıdır. Dolayısıyla teolojik açıdan dinsel çoğulculuk, felsefi bir alt yapıya sahiptir. Niyetimiz burada bunları açıklamak değildir. Fakat felsefi ve teolojik zemini ortaya konmadan çoğulculuğun sadece toplumsal birlik ve beraberliğin bir gereği olarak yansitılması, onun öneminin öğrenciler tarafından kavranmasına engel olacaktır. Gerçi ders kitabında dinsel çoğulculuğun felsefi ve teolojik temeline bir atff olarak "Her insan, mensubu olduğu dinin en doğru ve mükemmel din olduğuna inanur" denmiştir. ${ }^{24}$ Ancak bu yeterli değildir.

Kanaatimizce meselenin böyle kısa bir cümleyle geçiştirilmesi, dinsel çoğulculuk kavramından neyi anladığımızı tam olarak açıklamaz. Bunun yerine dinsel çoğulculuğun olası hedeflerinden önce "dışlayıcılık" ve "kapsayıcllk" kavramlarının ele alınması; söz konusu anlayışların toplumsal tezahürlerinin ortaya konması ve tarihsel örneklerle bunların desteklenmesi gerekir. Böylece bir arada yaşama kültürünün gelişmesinde dinsel çoğulculuğun önemi, öğrenciler için daha anlaşlır hale gelebilir. Bunun için öncelikle müfredat programınun amaçlarında yer bulan dinsel

22 Özbay, E. \& Diğerleri, İmam Hatip Liseleri Karşılaştırmalt Dinler Tarihi Ders Kitabı, ss. 164 165.

23 Mahmut Aydın, "Dinsel Çoğulculuk Üzerine Bir Müslüman Mülahazası", Hrristiyan, Yahudi ve Müslüman Perspektifinden Dinsel Çoğulculuk ve Mutlaklık İddiaları İçinde, (der.) Mahmut Aydin, Ankara: Ankara Okulu Yaymnları, 2005, s. 89.

24 Özbay, E. \& Diğerleri, İmam Hatip Liseleri Karş̧llaştırmalı Dinler Tarihi Ders Kitabı, s. 164. 
çoğulculuk kavramına ders kitabında daha fazla yer verilmelidir. Ayrıca ders kitabı çoğulcu bakış açısına göre yeniden düzenlenmeli ve dinsel geleneklerin karşılaştırılmasında çoğulcu bakış açısı bir "perspektif" olarak kullanılmalıdır. Zira hâlihazırda İmam Hatip liselerinde okutulan Karşlaştırmalı Dinler Tarihi ders kitabında dinsel çoğulculuk konusuna yaklaşık bir sayfa yer ayrılmıştır. Bu bağlamda yukarıda ifade ettiğimiz, "Dünya Dinleri" veya "Yaşayan Dünya Dinleri" adı altında bir dersin verilmesi dinsel geleneklerin anlatılmasında önemli bir adımdır. Ancak bu da yeterli değildir. İmam Hatip Liselerinde okutulan diğer meslek derslerinde köklü bir değişikler yapılmasının da önünün açılması gerekir. Bu bağlamda diğer meslek derslerinin çoğulcu bakış açısıyla verilmesi, en azından buna ters olmaması, dinler tarihi dersinin amacına ulaşması açısindan önem arz etmektedir. Aksi takdirde birbirini desteklemek yerine, birbirleriyle çelişen farklı meslek derslerinin öğrenciye yaşattı̆̆ kafa karı-

34 . şiklı̆ı̆ başka sorunların da önünü açacaktur. O halde, geldiğimiz bu nokOMÜifD tada şu sorunun cesaretle sorulması gerekir: Çoğulculuk fikri, sadece diğer dinlerin anlatıldığı bir dersin içeriğine mi hapsedilecek; yoksa Imam Hatip liselerinde okutulan diğer bazı meslek dersleri de dinsel çoğulculuk fikrinden hareketle yeniden gözden mi geçirilecek? Bu soruya verilecek cevaplar her ne olursa olsun, dinsel geleneklerin anlaşılma ve yorumlanma biçimlerini derinden etkileyecektir. Dersin muhatabı olan öğrencilerde diğer dinsel gelenekler hakkında oluşacak olumlu ya da olumsuz kanaatler, bir şekilde toplumsal hayatta karşlık bulacaktır. Zira eğitim ve öğretim, bütünlük isteyen bir süreçtir. Bu bütünlüğün hem müfredatta hem de bunun yansımaları olan ders kitaplarında karşılık bulması, geleceğin hangi esaslar altında şekilleneceğini göstermesi açsundan önemlidir. Bir arada yaşama, başkalarının inançlarına saygulı olma, çok kültürlülük gibi fikirler, yaşadığımız dünyada arık karşı konulamaz bir süreç olarak kabul ediliyorsa eğer Temel İslam Bilimleri alanunda değerlendirilen diğer meslek derslerinin büyük bir kısmınin da bu çerçevede yeniden gözden geçirilmesi ve söz konusu bütünlüğe uyum sağlayıcı konuma getirilmesi gerekmektedir. Böyle bir projenin sonucun- 
da olasıdır ki hem dinler tarihi dersine olan ilgi artacak hem öğrencinin zihninde oluşan kafa karışıklığı ortadan kalkacak hem de bir arada yaşama kültürünü ve çoğulculuğu benimsemiş, eğitimli bir din görevlisi nesli ortaya çıkacaktır.

Diğer yandan dünya dinlerinin yanında yeni dinsel hareketler, çağımızın yaygın dinsel akımlanı olarak ön plana çıkmaktadır. Günümüzde belki büyük dinler içerisinde yer almasa da binlerce yıllık geçmişe sahip olan dinlerden daha fazla taraftara sahip olan ve taraftar kitlesini sürekli genişleten dinsel hareketlerin varlığı artık yadsınamaz bir gerçek halini almıştır. Mevcut ders kitabında, misyonerlik faaliyetleri çerçevesinde Huristiyan gruplar ve Yahova Şahitleri dış̧ında söz konusu hareketler hakkında herhangi bir bilgi bulunmamaktadır. Din hizmeti alanında görevli olan kimselerin söz konusu akımlara üye olan kişilerle karşılaşması günümüzün koşulları dikkate alındığında olası bir durumdur. Bu bakımdan ders kitabının içeriğinde "Yeni Dinsel Hareketler" adı altında bir bölümün bulunması, bu hareketlerin hem amaç hem de öğretileri bağlamında ele alınması dersin amaçları açısından önem arz etmektedir. ${ }^{25}$

İfade etmeye çalıştı̆̆ımız şeyler, dinler tarihi dersinin amacına ulaşması için kayda değer olsa da yeterli değildir. Geldiğimiz bu noktada dikkatleri çekmek istediğimiz bir nokta daha var. O da dinsel geleneklerin anlatilmasında önemli bir kaynak olan öğretmen faktörüdür.

\section{Dinsel Geleneklerin Öğretiminde Meslek Dersleri Öğretmen Yeterlikleri}

Burada sorulması gereken temel soru, İmam Hatip liselerinde İslam dişındaki dinlerin öğretilmesinde önemli kaynak olan meslek dersleri öğretmenlerinin söz konusu ders programmın amaçlarında belirtilen hususlarda kayda değer bir yeterliğe sahip olup olmadığıdır. Bu konuda İmam Hatip Lisesi meslek dersleri öğretmenlerinin alan yeterliğini sorgulayan bir takım anket çalışmaları bize yardımcı olabilirdi. Ancak, eldeki anket

25 Aydın, "Dinler Tarihi Dersi Amaç, Yöntem, Muhteva ve İşlenişi", s. 358. 
çalışmalarına baktığımuzda tefsir, fikıh, hadis, siyer, Arapça gibi birçok meslek derslerinde öğretmenlerin alan yeterlikleri sorgulanmasına karşın Karşılaştırmalı Dinler Tarihi dersinin anket içerisinde yer almadığını görüyoruz. ${ }^{26}$ Anket çalışmalarında dahi meslek dersleri öğretmenlerinin alan yeterliklerinin ortaya çıkarılması konusunda kayda değer bulunmayan bir dersin ne kadar verimli olacağı ayrı bir tartışma konusudur. Bu bakımdan söz konusu liselerde diğer dinlerin öğretimi ile ilgili sağlıklı tespitlerin yapılabilmesi ve dersin verimliliğinin artrılabilmesi için öncelikle İmam Hatip liselerinde "Karşılaşırmah Dinler Tarihi" dersi özelinde öğretmen yeterlikleri ve öğrenci ilgileri konusunda bir çalışmanun yapılmasi gerekmektedir.

Bu konuda yerel ölçekte yapılmış ve öğrencilerin gözüyle meslek dersleri öğretmenlerinin dinler tarihi alanındaki yeterliklerini sorgulayan bir anket çalışması nispeten bize yardımcı olabilir. Söz konusu çalışmada öğrencilere, "diğer dinlerin öğretiminde öğretmenleriniz sizce yeterli bilgiye sahip mi?" sorusu yöneltilmiş ve ankete katılan İmam Hatip Lisesi öğrencilerinin \% 39.28'i yeterli; \%32.14' ü ise kısmen yeterli cevabin vermişlerdir. Diğer orta öğretim kurumlarında okuyan öğrencilerin bu soruya verdikleri olumlu cevap daha düşüktür. ${ }^{27}$ Anket çalş̧masından çıkan böyle bir sonuç,-çalışmanun sahibinin de yaptı̆̆ gibi- olumlu yorumlanabilir ve dinler tarihine giren meslek dersleri öğretmenlerinin çoğunlukla yeterli görüldüğü sonucu çıartılabilir. Fakat yazımızın başlarında da aktardığımız üzere ankete katılan İmam Hatip Lisesi öğrencilerinin yaklaşık \%60 gibi kısmının, diğer dinsel gelenekler konusunda kendilerini yetersiz veya kısmen yeterli gördükleri dikkate alındığında meslek dersleri öğretmen yeterlikleri için yeni önerilerin sunulması gerektiği ortaya çımaktadır.

26 Cuma Taşci, "İmam-Hatip Liselerinde Meslek Dersi Öğretiminin Yeterlik Durumu ve Meslek Dersi Öğretmenlerinin Temel Yeterliklere Sahip Olma Düzeyleri", Yayınlanmamış Yüksek Lisans Tezi, (Atatürk Üniversitesi Sosyal Bilimler Enstitüsü, 2006), s. 40.

27 Yllmaz, "AB’ye Giriş Sürecinde Ortaöğretimde Diğer Dinlerin Öğretimi İle İlgili Öğrencilerin Düşünceleri", s. 120. 
Öncelikle dinler tarihi dersinin, İmam Hatip liseleri meslek dersleri öğretmenleri arasında çok da tercih edilmeyen bir ders olduğu şeklindeki yaygın kanaatlerin olduğunu belirtmekte fayda var. Bu konuda yapılmış bilimsel bir araşturmadan henüz haberdar değiliz. Ancak özellikle ders dağıtımlarında dinler tarihinin -istisnalar olmakla birlikte- öğretmenler arasında sorun olduğu çeşitli ortamlarda dile getirilmektedir. Bunun temel sebebini, ilgili dersin hem yöntem hem de muhteva açısından diğer meslek derslerinden farkh olmasına bağlayan bir takım yorumlar yapılmıştır. Buna göre, diğer meslek dersleri muhteva ve yöntem bakımından birbirine yakın ve çoğu zaman birbirini tamamlayan derslerdir. Ancak dinler tarihi, yöntem ve içerik olarak diğer meslek derslerinden farkh kendine has bir disiplindir. Bu tarz yorumların haklllı payı olmakla birlikte sorunun metodolojik farklılıklara bağlanması, pratik çözüm için bize kayda değer bir fayda sağlamaz. Zira hâlihazırda ilahiyat fakültelerinde dinler tarihi kapsaminda değerlendirilebilecek zorunlu ve seçmeli dersler vardır. Bunların program açısından yeterli olup olmadığı ayn bir tartışma konusudur. Her ne olursa olsun ilahiyat fakültesi öğrencileri bu dersleri alarak mezun olmaktadırlar ve bu derslerin başarı düzeyleri de ancak mezunların mesleki çalışmalarda gün yüzüne çıkmaktadır. Bu noktada dinler tarihine özel ilgisi olan öğretmenlerin dersin aktarılmasında daha başarılı olabilecekleri şeklinde bir öngörüde bulunabilir. Zira dinler tarihi özel çaba gerektiren bir derstir. Bu özel çabalar, akademik çalışmalardan bağımsız olarak kişinin kendini yetiştirmesi şeklinde olabileceği gibi lisansüstï seviyedeki akademik çalışmalar şeklinde de olabilir. Her halükarda bu iki grubun İmam Hatip liselerinde dinsel geleneklerin öğretilmesinde yeterlik ve başarı düzeylerinin yüksek olabileceği tahmin edilebilir. Zaten çoğu zaman ders seçiminde bu iki gruba öncelik verildiği bilinmektedir. Dolayısıyla sorun, kendini yetiştiren bu iki grubun dışındaki çoğunluğun dinler tarihi açısından yeterlik düzeylerinin nasıl artırılacağıdır?

Sorun iki açıdan ele alınabilir. Birincisi, yukanda da ifade ettiğimiz üzere müfredat programmun daha verimli hale getirilmesi ve bir kaynak 
olarak ders kitabının içeriğinin yeniden ele alınmasıdır. Böylece çoğulcu bakışla çelişen öğretmen inisiyatifleri azaltılmış ve öğretmen yetersizliklerinden kaynaklanan sorunlar en aza indirilmiş olur. İkincisi ve daha etkin öneri ise, İmam Hatip liselerinde görev yapan meslek dersleri öğretmenlerine ilahiyat fakülteleri ve Milli Eğitim Bakanlığı bünyesinde "Dünya Dinleri", "Yeni Dinsel Hareketler" ve "Dinler Teolojisi" gibi ders programları açılabilir ve söz konusu derse girecek öğretmenlerin sertifika sahibi olmaları sağlanabilir. Böyle bir önerinin uygulanmasının zor olduğu düşünülse de son ylllarda ilahiyat fakültelerinin sayıları ve ülke çapındaki dağılımları dikkate alındığında bahsettiğimiz sertifika programlarının açılmasının sanıldığı kadar zor olmadığı görïlecektir. Zira hâlihazırda Türkiye'nin hemen her ilinde ilahiyat fakültesi bulunmaktadır. Yapılması gereken bir program hazırlayarak Milli Eğitim Bakanlığı ile ilahiyat fakülteleri arasında protokol imzalamaktr. Din Hizmetleri Genel

38 Müdürlügü bünyesinde uygun zamanlarda İmam Hatip Lisesi meslek

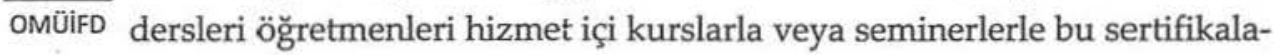
n alabilirler. Dinler tarihi dersine de ancak sertifika sahibi öğretmenlerin girmesi sağlanabilir. Böylece İmam Hatip liselerinde dinsel geleneklerin öğretilmesinde öğretmen yeterliği konusundaki kayglar büyük oranda giderilmiş olur. Burada yapılması gereken şey, uygun bir programun ortaya konması, bunun için akademisyenlerin görevlendirilmesi ve gerekli yasal prosedürlerin tamamlanmasıdır.

\section{Sonuç}

İmam Hatip liselerinde okutulan "Karşlaştirmalı Dinler Tarihi" dersini bağlamında bir takım tespit ve tekliflerin ele alındığı bu makalede ulaşılan sonuçları ve teklifler neticesinde oluşturulacak bir dinler tarihi dersinin olası faydaları şu şekilde ortaya konulabilir:

Birincisi, dinler tarihi dersinin günümüz çoğulcu toplumların yapısını ve kültürler arası iletişimi önceleyen bir tarzda ele alınması, bu dersi alan öğrencilerin diğer din mensuplarıyla iletişim kurmalarında pratik 
faydalar sağlayacaktır. Kültürler arası iletişimde öz güvenin önemi dikkate alındığında bu tarz bir eğitimin olası faydaları daha iyi anlaşılacaktır.

İkincisi, dinsel geleneklerin taraftarlarının yaşamlarında karşılık bulduğu şekliyle ele alınması, söz konusu geleneklerin daha objektif bir tarzda öğrenciye sunulmasını sağlayacaktır. Bu bağlamda, teolojik ön yargıların mümkün olduğunca önüne geçilecektir. Bunun için öncelikle "Karşlaştırmalı Dinler Tarihi" dersinden önce, genel dinler tarihi dersinin veya "Yaşayan Dünya Dinleri" adı altında bir dersin mutlaka verilmesi gerekmektedir.

Üçüncüsü, öğrenciler diğer dinsel gelenekleri öğrenmekle kendi inancının hem tarihsel hem de toplumsal bağlamdaki yerini daha iyi kavrayabilirler. Bu bağlamda İslam dininin dünya görüşü, diğer dinsel gelenekler nezdinde daha net ortaya çıkartılmış olur. Genel bir dinler tarihi dersinden sonra dinsel geleneklerin karşılaştırmalı olarak yeniden ele alınması, karşılaştırılan hususlarda öğrencilerin daha net olmalarına yar39 dım edecektir.

Dördüncüsü, İmam Hatip liselerinde teklif ettiğimiz çerçevede bir dinler tarihi öğretimiyle öğrenciler, evrensel ahlak ilkelerinin farkına varmış olurlar. Tüm dinlerin ahlaklı bir toplum oluşturmayı hedeflediği dinsel geleneklerin taraftarlarının yaşamlarında karşılık bulduğu şekliyle öğretildiği takdirde daha anlaşılabilir hale gelecektir. Bu bağlamda bir sonraki aşama, dinsel gelenekleri karşılaştırmalı olarak öğrenen her bir kimse, ahlaki ilkelerin evrensel bir karaktere sahip olduğunu görecektir. Ayrıca tüm dinlerin ortak değerleri konusunda da bir bilinç oluşturulmuş olur. Bunun yanunda her bir dinsel geleneğin kendi dinamiklerine sahip olduğu ve bu dinamikler çerçevesinde değerlendirilebileceği ortaya çıkar.

Altıncısı, dinsel geleneklerin öğretilmesinde bir perspektif olarak dinsel çoğulculuk fikri, hem teolojik açıdan hem de toplumsal açıdan ön plana çıkartıldığında bir arada yaşama kültürüne önemli ölçüde katkı sağlayacağı muhakkaktır. Bunun için İmam Hatip liselerinde sadece din- 
ler tarihi dersinin değil; diğer meslek derslerinin büyük bir çoğunluğunun da çoğulcu perspektifle yeniden ele alınmasında fayda olacaktır. Böylece dinler tarihi dersinin diğer meslek dersleriyle bağlantısinin kurulmașınun bir yolu da açılmış olacaktır. Öte yandan dışlayıcılık, kapsayıcıllk ve çoğulculuk açısından dinsel geleneklerin bir karşılaştırmasının yapılmasının imkânları da ortaya çıkmış olur. Günümüzde yaşayan dünya dinlerinin bu üç kavram çerçevesinde nerede durdukları ve hakikati anlamada ve aktarmada nasıl bir çaba içerisinde oldukları ve ne tür yöntemler önerdikleri görülebilir.

Tüm bu faydaların ortaya ç̧ıması ve kültürler arası iletişimde sağlıkh nesillerin yetiştirilebilmesi, dinler tarihi dersinin öğretiminde önerdiğimiz köklü değişiklerin dikkate alınmasın zorunlu kılmaktadır

\section{Kaynakça}

40 Altaș, Nurullah, "Liselerde Öğrencilerin Diğer Dinlere Karșı Tutumları (Ortaöğre$\overline{\text { MÜifF }}$ tim Din Kültürü ve Ahlak Bilgisi Öğretim Programlarında İslam Dini D1şındaki Dinlerin Öğretimi ve Uygulamaya Etkileri)", Dinler Tarihi AraşttrmaIarı VII, Türkiye'de Dinler Tarihi İçinde, İstanbul: Türkiye Dinler Tarihi Derneği Yayınları, 2010,ss. 673-703.

Aydın, Mahmut, "Dinler Tarihi Dersi Amaç, Yöntem, Muhteva ve İşlenişi", İmam Hatip Liselerinde Eğitim ve Öğretim İçinde, İstanbul: DEM Yayınları, 2005, ss. 353-365.

Aydın, Mahmut, "Dinsel Çoğulculuk Üzerine Bir Müslüman Mülahazası", Hrristiyan, Yahudi ve Müslüman Perspektifinden Dinsel Çoğulculuk ve Mutlaklık İddiaları İ̧̧inde, (der.) Mahmut Aydın, Ankara: Ankara Okulu Yayınları, 2005, ss. 87-128.

Baykara, Zeynep, "Okullarda Din Kültürü ve Ahlak Bilgisi Derslerinde Diğer Dinlerin Öğretimi", Yayınlanmamı̧̧ Yüksek Lisans Tezi, (Sakarya Üniversitesi Sosyal Bilimler Enstitüsü, 2009).

Bulut, Zübeyir, "Dinsel Çoğulculuk ve Ortaöğretim Din Kültürü ve Ahlak Bilgisi Dersinde Diğer Dinlerin Öğretimi" , Kelam Araşttrmalarn, 8 (2), 2010, ss. 6590.

Fiorenza, F. S., "Theological and Religious Studies: The Contest of the Faculties", In Shifting Boundaries: Contextual Approaches to the Structure of Theological Education, (Eds.) Barbara G. Wheeler \& Edward Farley, Louisville: John Knox Press, 1991, ss. 119-149. 


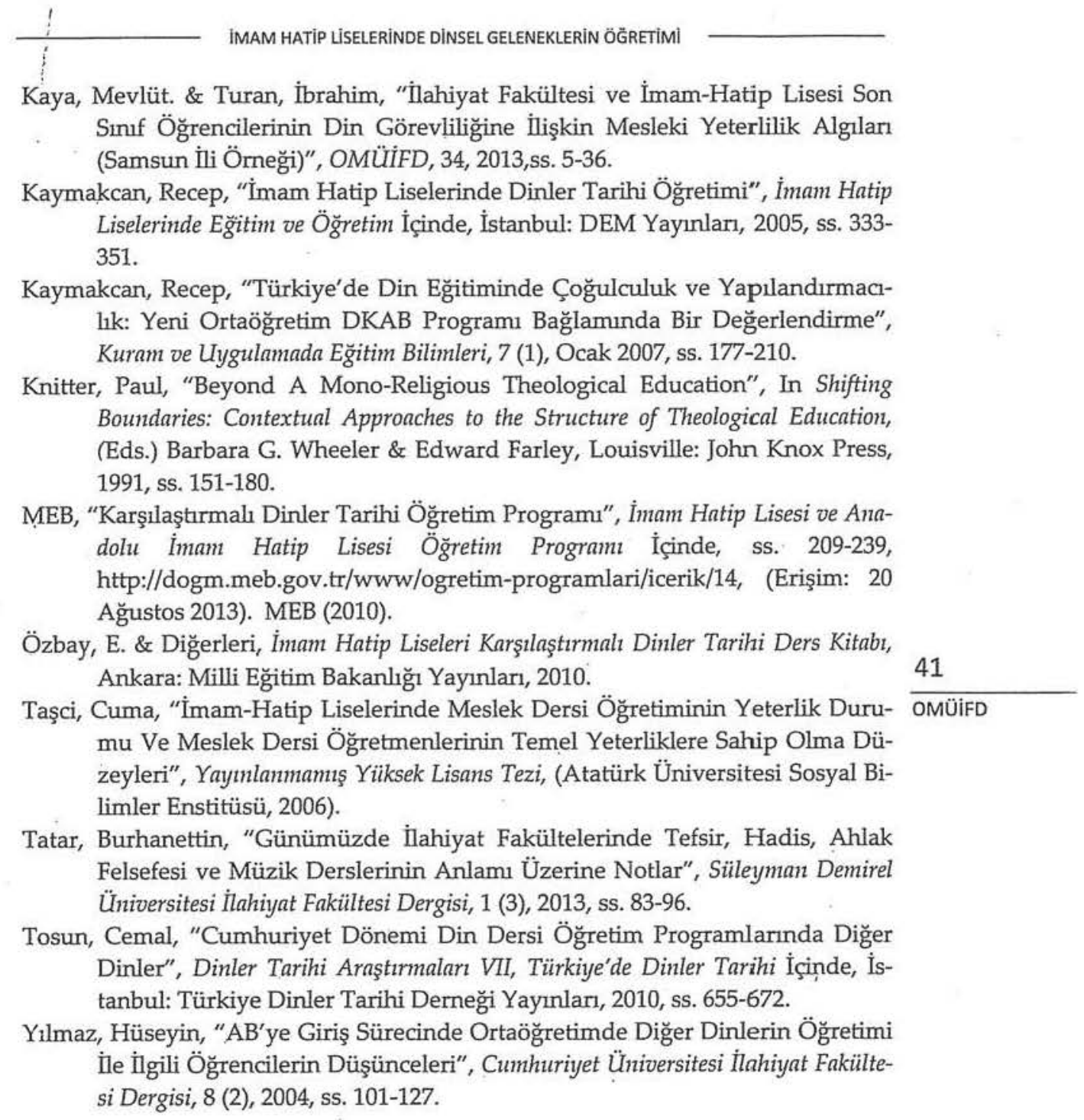

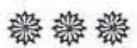

